Cite this: Analyst, 2013, 138, 5627

\title{
Detection of an estrogen derivative in two breast cancer cell lines using a single core multimodal probe for imaging (SCoMPI) imaged by a panel of luminescent and vibrational techniques $\uparrow$
}

\author{
Sylvain Clède, ${ }^{\text {abc }}$ François Lambert, ${ }^{\text {abc }}$ Christophe Sandt, ${ }^{d}$ Slavka Kascakova, ${ }^{e}$ \\ Miriam Unger, ${ }^{f}$ Etienne Harté, ${ }^{g}$ Marie-Aude Plamont, ${ }^{\text {h }}$ Rénette Saint-Fort, ${ }^{\text {, }}$ \\ Ariane Deniset-Besseau, ${ }^{i}$ Zoher Gueroui, ${ }^{\text {abj }}$ Carol Hirschmugl, ${ }^{\mathrm{f}}$ Sophie Lecomte, ${ }^{\mathrm{g}}$ \\ Alexandre Dazzi, ${ }^{i}$ Anne Vessières ${ }^{h}$ and Clotilde Policar ${ }^{\star a b c}$
}

3-Methoxy-17 $\alpha$-ethynylestradiol or mestranol is a prodrug for ethynylestradiol and the estrogen component of some oral contraceptive formulations. We demonstrate here that a single core multimodal probe for imaging - SCOMPI - can be efficiently grafted onto mestranol allowing its tracking in two breast cancer cell lines, MDA-MB-231 and MCF-7 fixed cells. Correlative imaging studies based on luminescence (synchrotron UV spectromicroscopy, wide field and confocal fluorescence microscopies) and vibrational (AFMIR, synchrotron FTIR spectromicroscopy, synchrotron-based multiple beam FTIR imaging, confocal Raman microspectroscopy) spectroscopies were consistent with one another and showed a Golgi apparatus distribution of the SCOMPI-mestranol conjugate in both cell lines.

Received 22nd April 2013 Accepted 1st July 2013

DOI: 10.1039/c3an00807j

www.rsc.org/analyst biological media). ${ }^{6}$ They are used for immunoassay ${ }^{7,8}$ and in a few cases of cellular mapping using $\mathrm{IR}^{5,9-13}$ or Raman spectroscopy. ${ }^{14,15}$ The smaller the probe, the less modified the physico-chemical properties of the molecule and its location in biological tissues will be. This is why small IR-tags are attractive. ${ }^{16}$ Interestingly metal-carbonyl bearing specific ancillary ligands with low $\pi^{*}$ orbitals are known to be luminescent. ${ }^{17,18}$ In the case of the rhenium-centred probes, emission properties allow their use in bio-imaging. ${ }^{19-26}$

Coupling IR and luminescence detection using metalcarbonyl can then be envisioned. Indeed, we have recently developed the concept of single core multimodal probe for imaging - SCoMPI - which corresponds to a unique organometallic complex showing complementary spectroscopic properties to achieve multimodal imaging in cells. As a proof of principle, we have shown that a rhenium tris-carbonyl complex with a 4-(2-pyridyl)-1,2,3-triazole (or pyta) ancillary ligand endowed with luminescent and infrared properties allowed a relevant bio-imaging correlative study using both modalities. ${ }^{12}$

In the present paper, we describe the investigation of the cellular location of an estrogen derivative conjugated with a metal-CO SCoMPI using correlative spectro-imaging. Estrogen signaling, trafficking and targeting are highly regulated mechanisms mediated by several factors. The first to be described was the $\alpha$ form of the nuclear estrogen receptors (ER $\alpha)^{27,28}$ In the late 1990s membrane-bound estrogen receptors were identified and among them was the 7-transmembrane $G$ protein-coupled estrogen receptor GPR30. ${ }^{29}$ The cell lines studied here are the 
archetypal of breast cancer cell lines, namely MCF-7 and MDAMB-231. They express different ER profiles since they are respectively (ER+, GPR30+) and (ER-, GPR30+). ${ }^{30-35}$ There are debates and controversies about GPR30's exact location ${ }^{\mathbf{3 6 , 3 7}}$ and several authors reported its main colocalization with the endoplasmic reticulum and/or the Golgi apparatus. ${ }^{35,38,39}$

Over the past thirty years several groups have worked on the synthesis of labelled estrogens, seeking for relevant imaging of estrogen receptors. ${ }^{40}$ Nuclear ER was successfully visualized by using fluorescent tetrahydrochrysen estrogens as labels in Cos-7 cells that express elevated levels of the receptor, but not in classic ER positive breast cancer cells such as MCF-7. ${ }^{41}$ Mapping studies involved radio-labelling of estrogens with halogen isotopes $\left({ }^{123} \mathrm{I}\right.$, $\left.{ }^{77} \mathrm{Br},{ }^{18} \mathrm{~F}\right),{ }^{42-44}$ estrogen-radiometal complexes based on $\mathrm{Tc}(\mathrm{I})$ radionuclides, ${ }^{45-47}$ intrinsic fluorescence of estrogen-like molecules $^{48}$ or estrogens tagged with fluorescent probes. ${ }^{4-55}$ Overall, the nuclear location was expected but rarely observed, which stresses the difficulty to visualize nuclear receptors, probably because of their low concentration. Combination of techniques in a multimodal approach would provide valuable cross-correlative information. ${ }^{56}$ Multimodal probes with complementary spectral properties, such as the SCoMPI we developed, ${ }^{\mathbf{1 2}}$ are relevant candidates to achieve this goal.

3-Methoxy-17 $\alpha$-ethynylestradiol or mestranol (MW 310.4) (Scheme 1) is the estrogen component of some oral contraceptive formulations and a prodrug leading to its active metabolite $17 \alpha$-ethynylestradiol. ${ }^{57,58}$ It was reported that bulky groups could be introduced without modifying the binding affinity at the $17 \alpha$-position. ${ }^{\mathbf{5 9 , 6 0}}$ It was tagged using click chemistry at position 17 by a metal-CO SCoMPI bearing an azide (MW 534.9), leading to 1 (MW 845.3). Using the bimodal properties of the SCoMPI complex, several techniques based on luminescence and vibrational spectroscopies were implemented to explore its cellular distribution in MCF-7 and MDA-MB-231 breast cancer cells through a correlative imaging approach.

Luminescence studies were performed using wide field and confocal fluorescent microscopies as well as synchrotron radiation UV spectromicroscopy (DISCO beam line, SOLEIL, Paris). Vibrational imaging was performed using synchrotron-based radiation FTIR with a raster scanning recording (SMIS beam line, SOLEIL, Paris), synchrotron-based multiple beam FTIR using a parallel recording with a focal plane array detector (IRENI beam line, SRC Madison), confocal Raman (CBMN, Bordeaux I) and AFMIR (CLIO centre, Paris-Sud university) spectromicroscopies. These techniques were applied to track 1 in fixed MCF-7 and/or MDA-MB-231 cells. All the mappings were
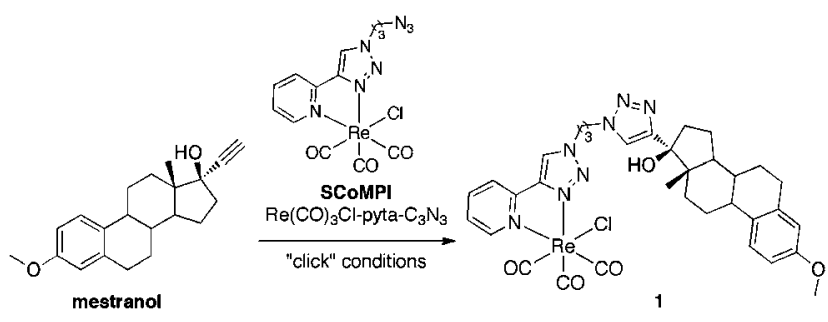

Scheme 1 consistent with one another and in agreement with colocalization of 1 with the Golgi apparatus.

\section{Results and discussion}

\subsection{Synthesis and characterization of 1}

Mestranol (Scheme 1) bears a terminal alkyne in the $17 \alpha$-position that can be used for Huisgen reaction and its copper-catalyzed click version (CuACC) $)^{\mathbf{6 1 , 6 2}}$ and thus was readily coupled to the azide group from $\mathrm{Re}(\mathrm{CO})_{3} \mathrm{Cl}-\mathrm{pyta}-\mathrm{C}_{3} \mathrm{~N}_{3}$. The two enantiomers of the facial $\mathrm{Re}(\mathrm{CO})_{3} \mathrm{Cl}$-pyta- $\mathrm{C}_{3} \mathrm{~N}_{3}$ (ref. 63-65) were not separated before coupling to the chiral mestranol, resulting in two diastereoisomers. These two diastereoisomers, bearing the same facial $\mathrm{Re}(\mathrm{CO})_{3} \mathrm{Cl}$-pyta moiety, are expected to show similar IR and luminescence properties. Indeed, as expected for a (pyta) $\operatorname{Re}(\mathrm{CO})_{3}$ central core, three bands are observed in the IR-spectrum in the 1800-2200 $\mathrm{cm}^{-1}$ range and a unique large MLCT band in the UV-visible absorption spectrum. In addition, the ${ }^{1} \mathrm{H}$ and ${ }^{13} \mathrm{C}$ NMR signal sets are very similar for the two diastereoisomers. ${ }^{60}$ The diastereoisomeric mixture was used without any separation and will be referred to as conjugate $\mathbf{1}$ (Scheme 1).

Conjugates involving metal-carbonyl complexes and estrogen derivatives are reported in the literature ${ }^{45,46,60,65-67}$ but, as far as we know, they were never used for infrared imaging. We previously showed that the rhenium tris-carbonyl moiety was reliable for sub-cellular IR-imaging ${ }^{5,11}$ using the strong infrared absorptions of CO stretching ( $\mathrm{E}$ and $\mathrm{A}_{1}$-bands in $\mathrm{C}_{3 \mathrm{v}}$ symmetry, respectively at $1915 \mathrm{~cm}^{-1}$ and $\left.2025 \mathrm{~cm}^{-1}\right) \cdot{ }^{68}$ It should be noted that the triple bond stretching vibration in the mestranol is far weaker than that of the $\mathrm{CO}$ in $\mathbf{1}$ and hence inappropriate for cellular imaging (see Fig. S2 $\dagger$ ). Rhenium-pyta tris-carbonyl complexes are luminescent upon excitation in a metal-to-ligand charge transfer (MLCT) broad band from 320-350 $\mathrm{nm}$ that deexcites at $c a .510 \mathrm{~nm} \cdot{ }^{69-71}$ As previously described, ${ }^{\mathbf{1 2}}$ this luminescence can be used for sub-cellular mapping. The spectral characteristics of 1 in IR and luminescence are shown on Fig. 1 (B and C frames, trace 3). It was shown to be lipophilic, with a $\log P_{\mathrm{o} / \mathrm{w}}$ of 5.7 (see Section 3.1), which is higher but close to the value for mestranol alone (4.7). ${ }^{57}$ This lipophilicity value remains yet in the range of analogous compounds dedicated to estrogen receptor targeting. ${ }^{53,72,73}$

\subsection{Biological assays and effect of the temperature on cellular uptake}

The in vitro effect of 1 on both hormone dependent (MCF-7) and hormone independent breast cancer cells (MDA-MB-231) was studied after 5 days of culture. On MCF-7 cells 1 shows a strong estrogenic proliferative effect at $1 \mu \mathrm{M}(142 \%$ of the control) and even at the low concentration of $10 \mathrm{nM}$ (157\% of the control). This effect is almost identical to that with $1 \mathrm{nM}$ of estradiol (174\% of the control) and is consistent with the estrogenic effect of mestranol at $10 \mathrm{nM} .^{74}$ These results indicate that despite the presence of a bulky substituent at the $17 \alpha$-position of estradiol, the complex is still able to interact with the estrogen receptor. This is not really surprising, as we have previously shown that the $17 \alpha$-position of estradiol is almost the only position in the 


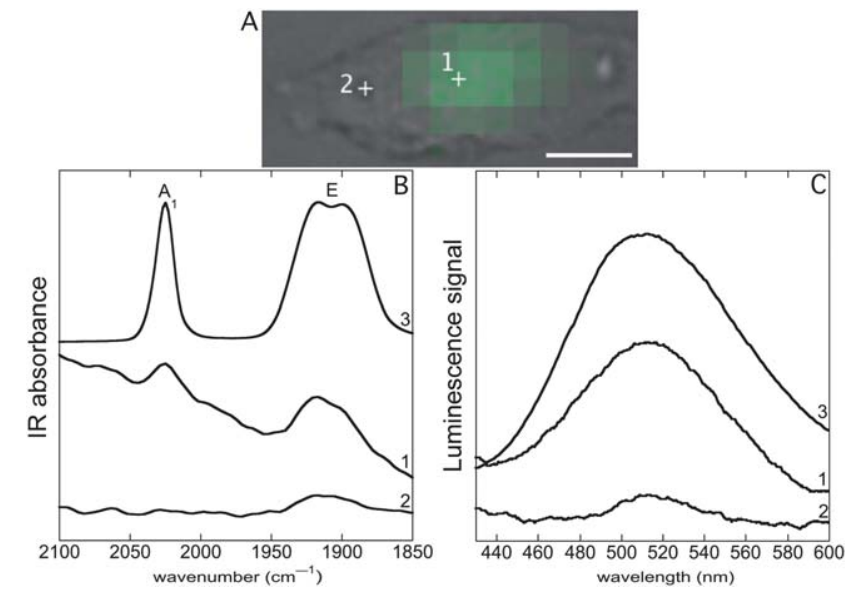

Fig. 1 SR-UV-SM and SR-FTIR-SM (Sections 3.7 and 3.8). Single MDA-MB-231 cell incubated with 1 ( $25 \mu \mathrm{M}, 1 \mathrm{~h}$ ), fixed and air-dried. (A) Bright field image, scale bar: $10 \mu \mathrm{m}$. Green pixels: intensity for the integral of the band of luminescence emission (450-550 $\mathrm{nm}$ ) recorded by SR-UV-SM after excitation at $350 \mathrm{~nm}$. (B) (1) and (2) SR-FTIR-SM spectra recorded respectively at locations 1 and 2 inside the cell, (3) FTIR spectrum of pure 1 (see Section 3.12 and Fig. S2†). (C) (1) and (2) SR-UV-SM spectra recorded respectively at locations 1 and 2 inside the cell, (3) luminescence emission after excitation at $350 \mathrm{~nm}$ of a solution of $\mathbf{1}$ at $10^{-4} \mathrm{M}$ in a DMSO : water (1:9) mixture.

steroid that is able to accommodate bulky substituents. ${ }^{59}$ In MDA-MB-231 cells 1 is toxic but in rather high concentrations $\left(\mathrm{IC}_{50}=4.6 \mu \mathrm{M} \pm 1.8\right)$.

The cellular uptake of the unconjugated probe $\mathrm{Re}(\mathrm{CO})_{3} \mathrm{Cl}-$ pyta- $\mathrm{C}_{3} \mathrm{~N}_{3}$ (see Scheme 1) was studied by fluorescence microscopy and synchrotron radiation UV spectromicroscopy and was almost insignificant (not shown), which suggests that the mestranol moiety is involved in the uptake of $\mathbf{1}$. The uptake of 1 was also further examined at $4{ }^{\circ} \mathrm{C}$, a temperature that abolishes active transport mechanisms ${ }^{75}$ and where only passive diffusion occurs, ${ }^{22,76,77}$ and compared with uptake at $37^{\circ} \mathrm{C}$. Quantification of the cellular uptake was performed by determining the mean perinuclear fluorescence intensity per cell after incubation with 1 at $25 \mu \mathrm{M}$, at $4{ }^{\circ} \mathrm{C}$ or at $37^{\circ} \mathrm{C}$ (see Section 3.6). Internalization of 1 was observed at $4{ }^{\circ} \mathrm{C}$ but this represented only $11 \%$ of the uptake at $37^{\circ} \mathrm{C}$ (Fig. S3-left $\dagger$ ). These results were compared with the uptake of the compound $\mathrm{Re}(\mathrm{CO})_{3} \mathrm{Cl}$-pyta- $\mathrm{C}_{12} \mathrm{~N}_{3}$ that we previously described. ${ }^{\mathbf{1 2}}$ This compound was shown to display a $\log P_{\mathrm{o} / \mathrm{w}}$ of 7.3 (the same method as that used for 1). Interestingly, $\mathrm{Re}(\mathrm{CO})_{3} \mathrm{Cl}$-pyta- $\mathrm{C}_{12} \mathrm{~N}_{3}$ displays an uptake at $4{ }^{\circ} \mathrm{C}$ representing $54 \%$ of the uptake at $37{ }^{\circ} \mathrm{C}$ (Fig. S3-right $\dagger$ ). This indicates that 1 enters cells by active transport to a larger extent than $\mathrm{Re}(\mathrm{CO})_{3} \mathrm{Cl}$-pyta- $\mathrm{C}_{12} \mathrm{~N}_{3}$ that does not bear the mestranol moiety, and suggests further that the penetration of $\mathbf{1}$ involves the mestranol moiety and its recognition.

In the following, we describe spectromicroscopy analyses of either MCF-7 or MDA-MB-231 breast cancer cell lines incubated with 1 under the same conditions $\left(25 \mu \mathrm{M}, 1 \mathrm{~h}, 37{ }^{\circ} \mathrm{C}\right)$ using several luminescent and IR imaging techniques. Note that most of the images were recorded with cells fixed and then air-dried, conditions required for IR-mapping. In two cases, the cells were fixed and then slides were mounted. Conditions are indicated in the figure captions and Sections 3.4 and 3.5.

\subsection{Synchrotron UV and IR spectromicroscopies (SR-UV-SM and SR-FTIR-SM)}

Fig. 1 shows SR-FTIR-SM and SR-UV-SM analyses of a single MDA-MB-231 cell incubated with 1 . The advantage of the synchrotron-based light is the highly focused beam hence allowing to record spectra at the subcellular level. At location 1, an intense luminescence emission of 1 obtained by excitation at $350 \mathrm{~nm}$ was recorded (Fig. 1C, trace 1). The spectrum matched with that of the pure compound in solution (Fig. 1C, trace 3). At location 2 , a very weak signal was recorded (Fig. 1C, trace 2). To generate a map of $\mathbf{1}$, the luminescent band obtained by excitation at $350 \mathrm{~nm}$ was integrated from 450 to $550 \mathrm{~nm}$ and Fig. 1A shows the location of $\mathbf{1}$ as green pixels the intensity of which corresponds to the integration values. A similar location was observed using the IR signals of $\mathbf{1}$ ( $\mathrm{E}$ and $\mathrm{A}_{1}$-bands, respectively at 1915 and $2025 \mathrm{~cm}^{-1}$ ) which were stronger where the luminescence signal was the highest (Fig. 1B, traces 1 and 2).

Fig. 2 shows SR-FTIR-SM and SR-UV-SM mappings of 1 obtained from a single MCF-7 cell incubated with 1. An IR-map was generated; ${ }^{\mathbf{1 1 , 1 2}}$ as previously described, the absorbance of a given IR-band was integrated-see limits of integration indicated in figure captions-and colored pixels are those showing more than $80 \%$ of the maximum integration value. These colored areas will be referred to as hot spots-see also Fig. $\mathrm{S} 4 \dagger$ for a mapping with the full range of integrated absorbance values. Showing IR hot spots superimposed on the bright field image enables a clear comparison between IR and luminescent imaging on the same cell.

The IR-map using the E-band of $\mathbf{1}$ (Fig. 2b) matched with that of the luminescence signal of $\mathbf{1}$ (Fig. 2d). Interestingly, as previously discussed, the nucleus can be located without any trackers using $\mathrm{CH}_{3}$ and $\mathrm{CH}_{2}$ IR-bands; ${ }^{78}$ the ratio of the $\mathrm{CH}_{3}$ asymmetric stretching band and the $\mathrm{CH}_{2}$ asymmetric stretching band is the highest at the nucleus and the lowest in the lipidrich organelles including the Golgi apparatus and the endoplasmic reticulum. Fig. 2a shows in blue the hot spot of the $\mathrm{CH}_{3} / \mathrm{CH}_{2}$ ratio, which thus corresponds to the nucleus. Fig. $2 \mathrm{c}$ hence indicates a perinuclear location of $\mathbf{1}$.

\subsection{Confocal Raman microspectroscopy and imaging}

MDA-MB-231 cells incubated with 1 were also analysed by confocal Raman microspectroscopy (see Section 3.10). The Raman spectrum of $\mathbf{1}$ in the solid state is shown in Fig. 3d (top black trace) and in Fig. S5. $\uparrow$ The characteristic vibrational modes of the $\operatorname{Re}(\mathrm{CO})_{3}$ moiety were observed at $1915 \mathrm{~cm}^{-1}$ and $2032 \mathrm{~cm}^{-1} .^{12}$ Additional bands from 1 are observed between 400 and $1800 \mathrm{~cm}^{-1}$, assigned to the stretching or the bending modes of the $\mathrm{C}=\mathrm{C}, \mathrm{N}=\mathrm{N}, \mathrm{C}-\mathrm{C}$ and $\mathrm{C}-\mathrm{N}$ bonds. An optical image of an MDA-MB-231 cell incubated with 1 is shown in Fig. 3a. The Raman image based on the CO stretching intensity gave the location of $\mathbf{1}$ in the same cell (Fig. 3b). Since CO-bands are weaker in Raman spectroscopy than in infrared spectroscopy it can be useful to take into account the other characteristic Raman bands of $\mathbf{1}$. The determination of the distribution of 1 was thus improved using the Hierarchical Cluster Analysis (HCA). ${ }^{79}$ A mask was selected based on the characteristic 

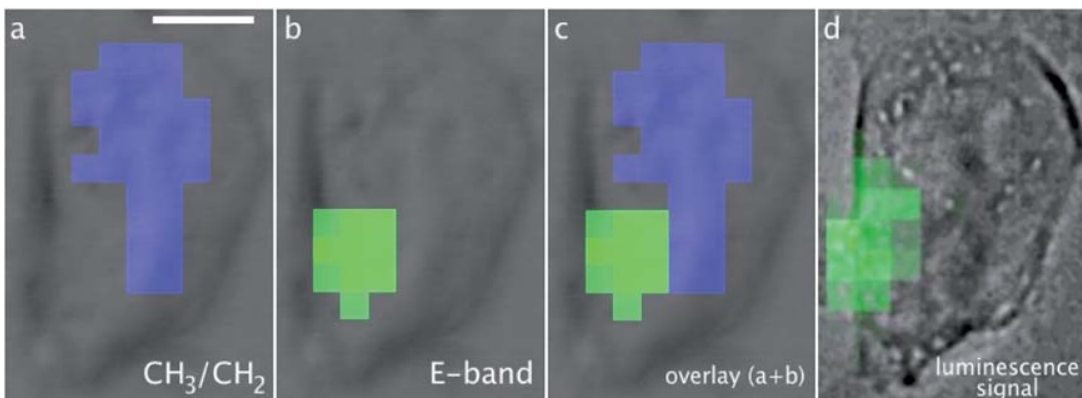

Fig. 2 SR-FTIR-SM and SR-UV-SM (Sections 3.7 and 3.8). A single MCF-7 cell incubated with $1\left(25 \mu \mathrm{M}, 1 \mathrm{~h}\right.$ ), fixed and air-dried. Scale bar: $10 \mu \mathrm{m}$. Pixel size $3 \times 3 \mu \mathrm{m}^{2}$. Hot spots of the integral of IR bands: (a) $\mathrm{CH}_{3} / \mathrm{CH}_{2}$ ratio (using the $\mathrm{CH}_{3}$ asymmetric stretching band from 2986 to $2948 \mathrm{~cm}^{-1}$ and the $\mathrm{CH}_{2}$ asymmetric stretching band from 2948 to $2897 \mathrm{~cm}^{-1}$ ), (b) E-band (1940-1879 cm ${ }^{-1}$ ), (c) overlay $\mathrm{CH}_{3} / \mathrm{CH}_{2}+\mathrm{E}$-band. Integration of the band of luminescence (d) (450-550 nm) recorded by SR-UVSM after excitation at $350 \mathrm{~nm}$. Note that the bright field image in (d) was collected on a different microscope compared to those in (a-c).
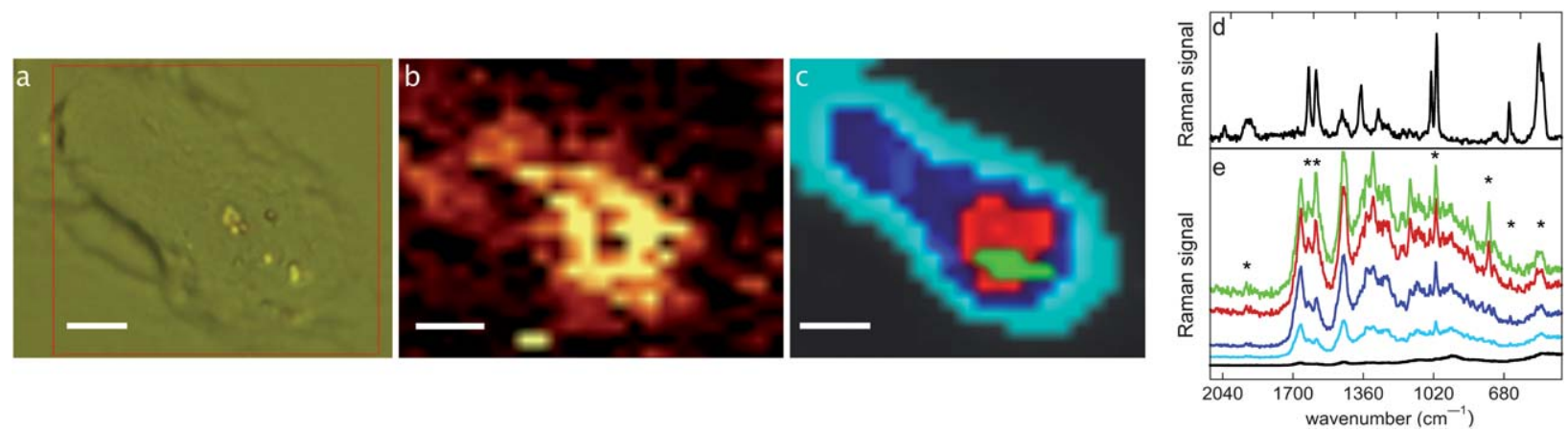

Fig. 3 Confocal Raman microspectroscopy (Section 3.10). A single MDA-MB-231 cell incubated with 1 ( $25 \mu \mathrm{M}, 1 \mathrm{~h}$ ), fixed and air-dried. Scale bars: $4 \mu \mathrm{m}$. (a) Bright field image, the red frame corresponds to the measured area, (b) Raman image of the integration of the CO stretching band at $1926 \mathrm{~cm}^{-1}$, (c) results of the HCA analysis, (d) Raman spectrum of $\mathbf{1}$ in the solid state, and (e) cluster average spectra from HCA results (the trace color corresponds to the area in (c)).

vibrational bands of $\mathbf{1}$ (Fig. S5 $\dagger$ ) and the HCA process was performed with five cluster areas in the mapping. Fig. $3 \mathrm{c}$ displays a color representation of the HCA calculated cluster areas. The average spectrum of each cluster area resulting from the HCA uses the same color code (Fig. 3e). The bottom black spectrum shows no significant band, as expected due to the location out of the cell; it mainly reveals characteristic bands of the glass slide where the cells grew. From cyan to green, an increase in intensity in the CO bands was observed, showing an inhomogeneous distribution of $\mathbf{1}$ inside the cell. Raman signals of $\mathbf{1}$ were weak in the blue and cyan parts of the cell, but higher in the red and green parts of the cell, indicating an accumulation of $\mathbf{1}$ in the red and green areas. It is noteworthy that in the average cluster spectra of the red and green parts, not only the CO stretching can be observed but also other characteristic bands of 1 at $1627 \mathrm{~cm}^{-1}, 1590 \mathrm{~cm}^{-1}, 1000 \mathrm{~cm}^{-1}, 755 \mathrm{~cm}^{-1}$, $648 \mathrm{~cm}^{-1}$ and $500 \mathrm{~cm}^{-1}$ (see stars in Fig. 3e) can be observed. As expected, none of the bands was observed in the analysis of the control cell (Fig. S6 + ). This distribution is consistent with that obtained with the other imaging techniques, showing that $\mathbf{1}$ can be mapped by Raman spectroscopy.

\subsection{Synchrotron-based multiple beam FTIR imaging}

Fig. 4 shows the FTIR average spectra of a control (trace 2) and an incubated MDA-MB-231 cell with 1 (trace 1) in the region
$2150-1600 \mathrm{~cm}^{-1}$. Specific absorption bands of 1 are observed at $1915 \mathrm{~cm}^{-1}$ (E-band) and $2025 \mathrm{~cm}^{-1}$ (A $\mathrm{A}_{1}$-band). The spectra demonstrate the detection of 1 inside a single MDA-MB-231 cell using an IRENI set-up. In order to determine the distribution of 1, IRENI images were developed by integration of the individual absorption bands of interest. In Fig. 5 visible images and intensity distributions of amide $\mathrm{I}, \mathrm{E}$ - and $\mathrm{A}_{1}$-bands of a control cell (series A) and an incubated cell (series B) are displayed (see Section 3.11 for integration parameters). Chemical images of

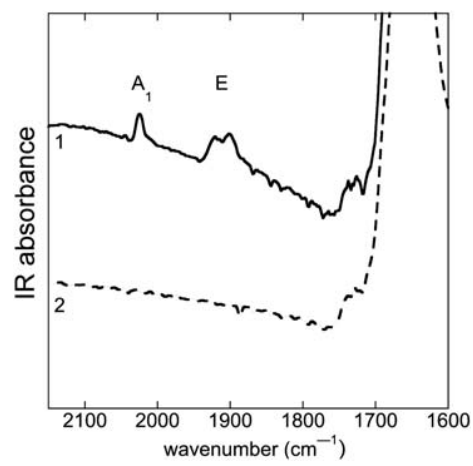

Fig. 4 FTIR average spectra recorded with IRENI (Section 3.11) on single MDAMB-231 cells, fixed and air-dried. (1) Single cell incubated with 1 ( $25 \mu \mathrm{M}, 1 \mathrm{~h})$; (2) single control cell. Amide I and CO ester bands appear respectively at 1650 and $1735 \mathrm{~cm}^{-1}$. 

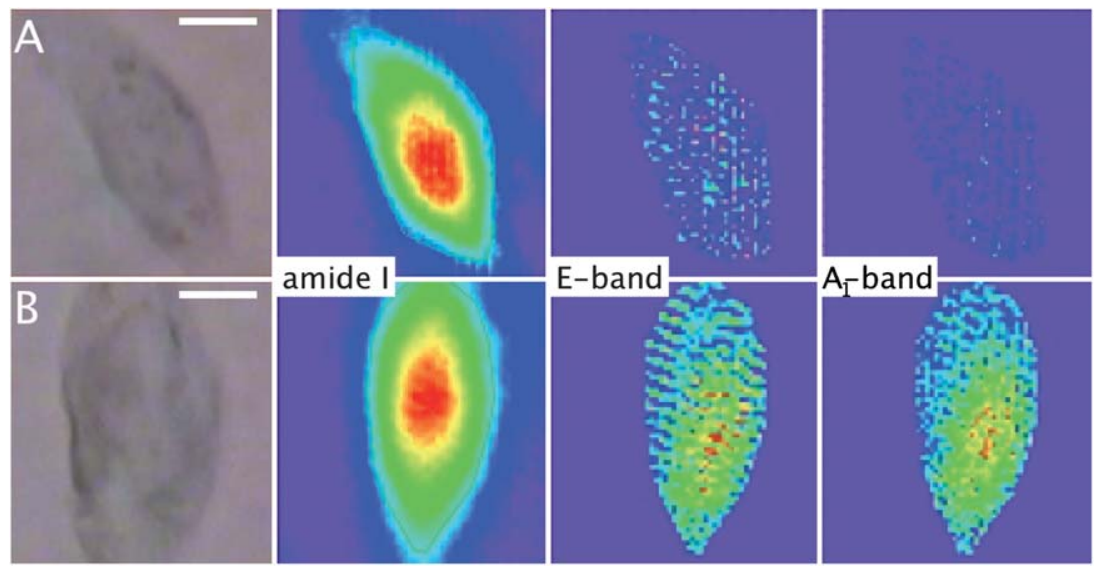

Fig. 5 Synchrotron-based multiple beam FTIR imaging (Section 3.11). Visible and FTIR images based on the integration of specific absorption bands. Scale bars: $10 \mu$ m. (A) A single MDA-MB-231 control cell. (B) A single MDA-MB-231 cell incubated with 1 ( $25 \mu \mathrm{M}, 1 \mathrm{~h}$ ). See Section 3.11 for integration parameters. Constant scaling of the contour colors has been applied for each band, with red/purple equivalent to high/low absorption intensity. All cells were fixed and air-dried.

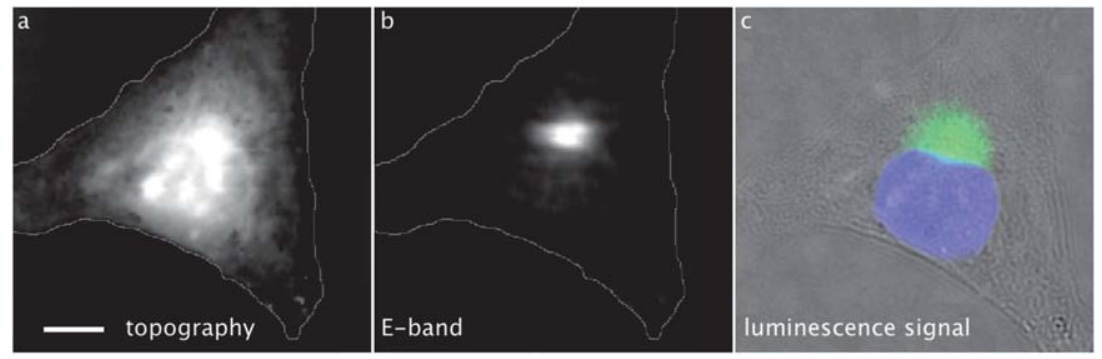

Fig. 6 MCF-7 breast cancer cell incubated with $1(25 \mu \mathrm{M}, 1 \mathrm{~h})$, fixed and air-dried. Scale bar: $10 \mu \mathrm{m}$. AFMIR imaging (Section 3.9): (a) topography of the cell recorded with the AFM (maximum of altitude $2.2 \mu \mathrm{m}$; cell outline drawn in gray), (b) AFMIR mapping of the E-band of 1 (laser tuned at $1920 \mathrm{~cm}^{-1}$ ); fluorescence imaging (Section 3.6): (c) bright field image merged with nucleus staining (DAPI, blue) and luminescence signal of $\mathbf{1}$ (green).

replicate measurements of control and incubated cells are shown in Fig. S7. $\dagger$ The contour colors vary between red and dark violet, where red indicates the highest and dark violet indicates the lowest value of the band integration. For better comparison of the chemical images, constant scaling of the contour colors has been applied as a visualization tool for each individual functional group for displaying the differences of the control and incubated cell. Based on the chemical images of the cell incubated with 1 (Fig. 5, series B), it can be seen that $\mathbf{1}$ was heterogeneously distributed in the cell and localized in regions of low amide absorption or partly overlaid with the amide-rich region that can be assigned to the nucleus. ${ }^{\mathbf{8}}$ The IRENI results were thus in agreement with the previous luminescence and IR findings, pointing out a perinuclear distribution of $\mathbf{1}$.

\subsection{Correlation between AFMIR and fluorescence imaging}

MCF-7 cells grown on thin $\mathrm{CaF}_{2}$ slides and incubated with 1 were mapped using both AFMIR (see Section 3.9) and fluorescence microscopy on the same cells. The AFMIR signal upon irradiation in the E-band of $\mathbf{1}$ is shown in Fig. $6 \mathrm{~b}$.

This mapping does not correspond to all the topographic bulges recorded by the AFM tip (Fig. 6a). Interestingly the AFMIR signal for $\mathbf{1}$ matches with the luminescence signal of $\mathbf{1}$ (Fig. 6c, green). The nucleus was stained with DAPI (Fig. 6c, blue) and the mapping clearly shows that $\mathbf{1}$ has a perinuclear location.

Overall all these imaging techniques point out a perinuclear localization of $\mathbf{1}$ both in MDA-MB-231 and MCF-7 cell lines. To better characterize this location, we performed colocalization experiments using fluorescence microscopy.

\subsection{Colocalization studies}

Fig. 7 shows the colocalization experiments between $\mathbf{1}$ (green), a Golgi tracker (BODIPY-TR $\mathrm{C}_{5}$-ceramide, red) and DAPI (blue) in MDA-MB-231 and MCF-7 cell lines. Comparison of Fig. 7-A1 with $\mathrm{A} 2$ and B1 with B2 clearly showed an accumulation of $\mathbf{1}$ in a region outside the nucleus in both cell lines. This observation was confirmed by confocal microscopy (Fig. 8). It was also in agreement with the exclusion of the region with high $\mathrm{CH}_{3} / \mathrm{CH}_{2}$ ratio obtained in IR studies (Fig. 2c). Colocalization with the Golgi tracker was clearly shown in Fig. 7A2, A3 and B2, B3, with very high quantitative coefficients for both cell lines (Table 1)..$^{81,82}$

The observation of a strong proliferative effect induced in MCF-7 cells with a low concentration of 1 (see Section 3.2) demonstrated that 1 was recognized by nuclear estrogen receptors, known to be responsible for this proliferative effect. ${ }^{83}$ However, the amount of nuclear estrogen receptors is known to 


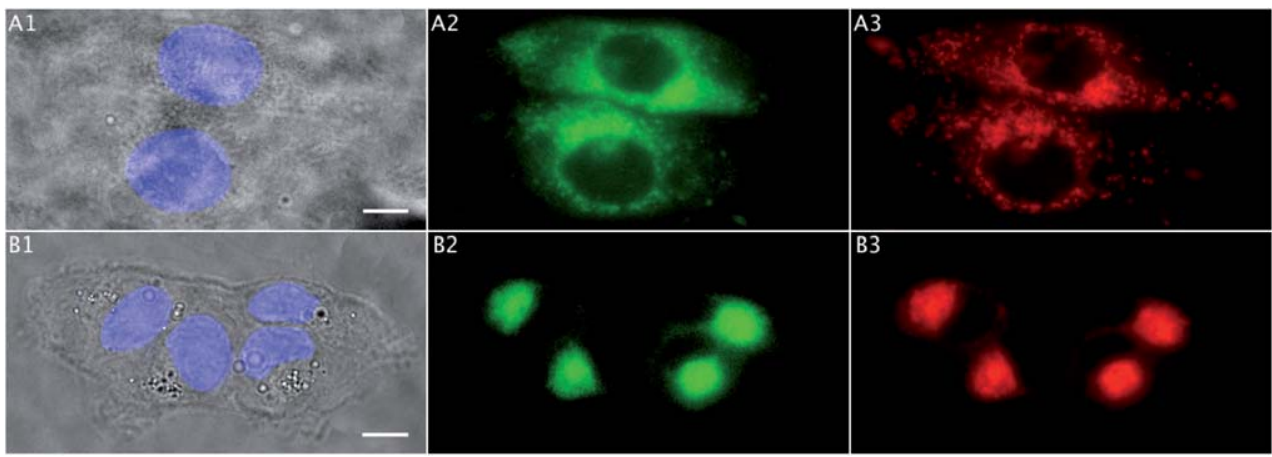

Fig. 7 Colocalization studies (Sections 3.5 and 3.6). (A) Two MCF-7 breast cancer cells incubated with 1 ( $25 \mu \mathrm{M}, 1 \mathrm{~h}$ ): (A1) bright field image (scale bar: $10 \mu \mathrm{m})$ and the nucleus stained with DAPI (blue), (A2) 1 in green, (A3) Golgi tracker in red. (B) Four MDA-MB-231 breast cancer cells incubated with 1 (25 $\mu$ M, 1 h): (B1) bright field image (scale bar: $10 \mu \mathrm{m}$ ) and the nucleus stained with DAPI (blue), (B2) 1 in green, (B3) Golgi tracker in red. All cells were fixed and slides were mounted.

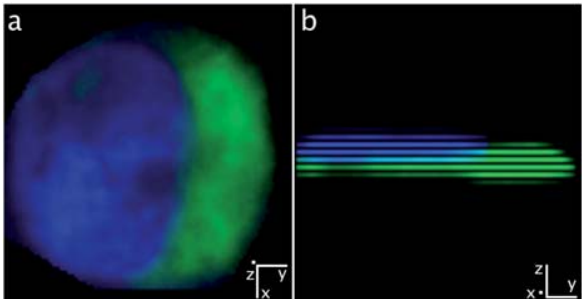

Fig. 8 Confocal fluorescence microscopy (Section 3.6). A single MDA-MB-231 cell incubated with $\mathbf{1}(25 \mu \mathrm{M}, 1 \mathrm{~h})$. All cells were fixed and slides were mounted. Confocal images of $\mathbf{1}$ (green) and DAPI (blue): (a) along the $z$-axis and (b) along the $x$-axis (clockwise rotation of $90^{\circ}$ along the $y$-axis from (a) to (b)).

Table 1 Quantitative analysis of the colocalization between 1 and the Golgi tracker in Fig. 7

\begin{tabular}{llll}
\hline & $\begin{array}{l}\text { Pearson's } \\
\text { coefficient } \\
(-1<x<1)\end{array}$ & $\begin{array}{l}\text { Overlap } \\
\text { coefficient } \\
(0<x<1)\end{array}$ & $\begin{array}{l}\text { Intensity } \\
\text { correlation } \\
\text { quotient }(0<x<0.5)\end{array}$ \\
\hline A2 and A3 & 0.90 & 0.95 & 0.35 \\
B2 and B3 & 0.95 & 0.94 & 0.41
\end{tabular}

be very low, actually in the range of a picomole per mg of DNA, ${ }^{84}$ which can explain why $\mathbf{1}$ was not detected in the nucleus with the techniques used here, due to limits in the detection sensitivity, as previously pointed out by Rickert et al..$^{52}$

Images obtained in Fig. 7 were very similar to those from the literature $^{35}$ for the localization of GPR30 in MCF-7 and MDAMB-231 cells showing a perinuclear distribution. Several groups reported that GPR30 is mainly found in the internal membranes ${ }^{85}$ with a predominant expression in the endoplasmic reticulum ${ }^{86}$ or the Golgi apparatus. ${ }^{38,39}$ The purpose here was not to solve this controversy and at that point, we cannot exclude a non-specific localisation of the labelled mestranol 1. However, this multimodal approach allowed us to obtain information from independent imaging techniques about the intracellular main location of $\mathbf{1}$. The convergent results obtained are clearly in favour of accumulation of 1 in the Golgi apparatus in both cell lines.

\section{Experimental section}

\subsection{Synthesis and characterization}

Sodium azide (5 g, $\left.7.7 \times 10^{-2} \mathrm{~mol}\right)$ and 3-bromopropan-1-ol $\left(\mathrm{Br}\left(\mathrm{CH}_{2}\right)_{3} \mathrm{OH}, 5 \mathrm{~g}, 3.6 \times 10^{-2} \mathrm{~mol}\right)$ were dissolved in water $(50 \mathrm{~mL})$ and heated at $60{ }^{\circ} \mathrm{C}$ overnight. After cooling to r.t., 3-azidopropan-1-ol was extracted with $\mathrm{CH}_{2} \mathrm{Cl}_{2}(3 \times 100 \mathrm{~mL})$. The organic fractions were combined and dried over anhydrous sulfate magnesium and evaporated to dryness. The yield was quantitative.

3-Azidopropan-1-ol was directly added $\left(1 \mathrm{~g}, 9.7 \times 10^{-3} \mathrm{~mol}\right)$ with 2-ethynylpyridine $\left(1 \mathrm{~g}, 9.7 \times 10^{-3} \mathrm{~mol}\right)$ to a mixture of $\mathrm{CH}_{2} \mathrm{Cl}_{2}(5 \mathrm{~mL})$ and water $(5 \mathrm{~mL})$ at r.t. Sulfate copper(II) pentahydrate $\left(250 \mathrm{mg}, 1.0 \times 10^{-3} \mathrm{~mol}\right)$ and sodium ascorbate $\left(500 \mathrm{mg}, 2.0 \times 10^{-3} \mathrm{~mol}\right)$ were then added. After overnight stirring, water $(10 \mathrm{~mL})$ and $\mathrm{CH}_{2} \mathrm{Cl}_{2}(10 \mathrm{~mL})$ were poured into the mixture. The product was extracted with $\mathrm{CH}_{2} \mathrm{Cl}_{2}(2 \times 30 \mathrm{~mL})$, the organic fractions combined, dried over anhydrous sulfate magnesium and evaporated to dryness. Silica gel column chromatography with $\mathrm{CH}_{2} \mathrm{Cl}_{2}: \mathrm{MeOH}$ (from $1: 0$ to $95: 5$ ) gave 4-(2-pyridyl)-1,2,3-triazole-( $\left.\mathrm{CH}_{2}\right)_{3}$-OH $\left(1.6 \mathrm{~g}, 7.8 \times 10^{-3} \mathrm{~mol}\right.$, $80 \%$ yield) as a white solid. In the following, this product is referred to as pyta- $\left(\mathrm{CH}_{2}\right)_{3}-\mathrm{OH}$.

Pyta- $\left(\mathrm{CH}_{2}\right)_{3}-\mathrm{OH}\left(1 \mathrm{~g}, 5 \times 10^{-3} \mathrm{~mol}\right)$ and 4-toluenesulfonyl chloride $\left(950 \mathrm{mg}, 5 \times 10^{-3} \mathrm{~mol}\right)$ were dissolved in $\mathrm{CH}_{2} \mathrm{Cl}_{2}$. The solution was cooled with an ice bath and potassium hydroxide $\left(1.12 \mathrm{~g}, 2 \times 10^{-2} \mathrm{~mol}\right)$ was poured into the mixture that remained at $0{ }^{\circ} \mathrm{C}$ for $3 \mathrm{~h}$ under stirring. Ice $(30 \mathrm{~g})$ was added and the tosylated compound was extracted with $\mathrm{CH}_{2} \mathrm{Cl}_{2}(2 \times 100 \mathrm{~mL})$, the organic fractions combined, dried over anhydrous sulfate sodium and evaporated to dryness. Silica gel column chromatography with $\mathrm{CH}_{2} \mathrm{Cl}_{2}: \mathrm{MeOH}(99: 1)$ gave pyta- $\left(\mathrm{CH}_{2}\right)_{3}$-OTs $(1.6 \mathrm{~g}, 4.5 \times$ $10^{-3}$ mol, $90 \%$ yield) as a white solid.

Pyta- $\left(\mathrm{CH}_{2}\right)_{3}$-OTs $\left(2.9 \mathrm{~g}, 8.1 \times 10^{-3} \mathrm{~mol}\right)$ and sodium azide $\left(1.65 \mathrm{~g}, 2.5 \times 10^{-2} \mathrm{~mol}\right)$ were dissolved in DMF $(50 \mathrm{~mL})$ and heated at $70{ }^{\circ} \mathrm{C}$ overnight. After cooling to r.t., pyta- $\left(\mathrm{CH}_{2}\right)_{3}-\mathrm{N}_{3}$ was extracted with $\mathrm{Et}_{2} \mathrm{O}(2 \times 30 \mathrm{~mL})$. Organic fractions were combined, dried over anhydrous sulfate magnesium and evaporated to dryness. The yield was quantitative. See the ESI $\uparrow$ for the atom numbering. 
Pyta- $\left(\mathrm{CH}_{2}\right)_{3}-\mathrm{N}_{3}{ }^{1} \mathrm{HNMR}\left(\mathrm{CDCl}_{3}, 250 \mathrm{MHz}\right) \delta(\mathrm{ppm}): 8.47(1 \mathrm{H}, \mathrm{d}, \mathrm{J}$ $\left.=4.5 \mathrm{~Hz}, 6^{\prime}-\mathrm{pyH}\right), 8.10\left(1 \mathrm{H}, \mathrm{s}, 5^{\prime \prime}\right.$-triazH), $8.06(1 \mathrm{H}, \mathrm{d}, J=8.0 \mathrm{~Hz}$, $3^{\prime}$-pyH), 7.67 (1H, m, 4'-pyH), 7.12 (1H, m, 5'-pyH), $4.42(2 \mathrm{H}, \mathrm{t}, J=$ $\left.6.4 \mathrm{~Hz}, \mathrm{CH}_{2}\right), 3.29\left(2 \mathrm{H}, \mathrm{t}, J=6.7 \mathrm{~Hz}, \mathrm{CH}_{2}\right), 2.11\left(2 \mathrm{H}, \mathrm{m}, \mathrm{CH}_{2}\right)$.

Pyta- $\left(\mathrm{CH}_{2}\right)_{3}-\mathrm{N}_{3}{ }^{13} \mathrm{C} \mathrm{NMR}\left(\mathrm{CDCl}_{3}, 62.5 \mathrm{MHz}\right) \delta(\mathrm{ppm}):$ 150.10, 149.37, 148.46, 136.99, 122.95, 122.35, 120.23, 47.99, 47.33, 29.48.

Rhenium pentacarbonyl chloride (500 mg, $1.4 \times 10^{-3} \mathrm{~mol}$ ) and pyta- $\left(\mathrm{CH}_{2}\right)_{3}-\mathrm{N}_{3}\left(360 \mathrm{mg}, 1.6 \times 10^{-3} \mathrm{~mol}\right)$ were dissolved in toluene $(20 \mathrm{~mL})$ and heated for $3 \mathrm{~h}$ at $70{ }^{\circ} \mathrm{C}$. A precipitate was formed when cooled to r.t. Filtration led to a yellow solid of $\mathrm{Re}(\mathrm{CO})_{3} \mathrm{Cl}$-pyta- $\left(\mathrm{CH}_{2}\right)_{3}-\mathrm{N}_{3}\left(178 \mathrm{mg}, 3.4 \times 10^{-4} \mathrm{~mol}, 25 \%\right.$ yield$)$. The conjugation with the tricarbonyl-chloro-rhenium core through the pyta ligand provided a stereogenic metal centre. ${ }^{64}$ $\mathrm{Re}(\mathrm{CO})_{3}$ Cl-pyta- $\left(\mathrm{CH}_{2}\right)_{3}-\mathrm{N}_{3}$ was obtained as a racemic mixture. See the $\mathrm{ESI} \dagger$ for the atom numbering.

$\mathrm{Re}(\mathrm{CO})_{3} \mathrm{Cl}$-pyta- $\left(\mathrm{CH}_{2}\right)_{3}-\mathrm{N}_{3}{ }^{1} \mathrm{H} \mathrm{NMR}\left(\mathrm{CDCl}_{3}, 250 \mathrm{MHz}\right) \delta(\mathrm{ppm})$ : $9.02\left(1 \mathrm{H}, \mathrm{d}, J=5.4 \mathrm{~Hz}, 6^{\prime}\right.$-pyH), $8.41\left(1 \mathrm{H}, \mathrm{s}, 5^{\prime \prime}\right.$-triazH), $8.00(1 \mathrm{H}$, $\mathrm{m}, 4^{\prime}$-рyH), 7.87 (1H, d, $\left.J=7.8 \mathrm{~Hz}, 3^{\prime}-\mathrm{pyH}\right), 7.48$ (1H, m, 5'-pyH), $4.57\left(2 \mathrm{H}, \mathrm{t}, J=6.9 \mathrm{~Hz}, \mathrm{CH}_{2}\right), 3.47\left(2 \mathrm{H}, \mathrm{t}, J=6.1 \mathrm{~Hz}, \mathrm{CH}_{2}\right), 2.25$ $\left(2 \mathrm{H}, \mathrm{m}, \mathrm{CH}_{2}\right)$.

$\mathrm{Re}(\mathrm{CO})_{3} \mathrm{Cl}$-pyta- $\left(\mathrm{CH}_{2}\right)_{3}-\mathrm{N}_{3}{ }^{13} \mathrm{C} \mathrm{NMR}$ (acetone, $\left.75 \mathrm{MHz}\right) \delta(\mathrm{ppm})$ : 153.07, 149.49, 148.77, 140.16, 126.13, 125.31, 122.46, 49.46, 48.01, 29.29.

$\mathrm{Re}(\mathrm{CO})_{3} \mathrm{Cl}$-pyta- $\left(\mathrm{CH}_{2}\right)_{3}-\mathrm{N}_{3}\left(178 \mathrm{mg}, 3.4 \times 10^{-4} \mathrm{~mol}\right)$ and 3methoxy-17 $\alpha$-ethynylestradiol (or mestranol) $(100 \mathrm{mg}, 3.2 \times$ $\left.10^{-4} \mathrm{~mol}\right)$ were dissolved in a mixture of $\mathrm{CH}_{2} \mathrm{Cl}_{2}(5 \mathrm{~mL})$ and water $(5 \mathrm{~mL})$ at r.t. Sulfate copper(II) pentahydrate $(8 \mathrm{mg}, 3.2 \times$ $\left.10^{-5} \mathrm{~mol}\right)$ and sodium ascorbate $\left(13 \mathrm{mg}, 6.5 \times 10^{-5} \mathrm{~mol}\right)$ were then added. After overnight stirring at r.t., water $(10 \mathrm{~mL})$ and $\mathrm{CH}_{2} \mathrm{Cl}_{2}(10 \mathrm{~mL})$ were poured into the mixture. The product was extracted with $\mathrm{CH}_{2} \mathrm{Cl}_{2}(2 \times 30 \mathrm{~mL})$, the organic fractions combined, dried over anhydrous sulfate sodium, and evaporated to dryness. Silica gel column chromatography with AcOEt : acetone (from $1: 0$ to $7: 3)$ gave $1\left(180 \mathrm{mg}, 2.1 \times 10^{-4}\right.$ mol, $66 \%$ yield) as a pale yellow solid.

Because of the facial coordination geometry of the Re complex and the chirality of the steroid substituent, a mixture of diastereoisomers was formed, in a $1: 1$ ratio. Attempts to separate these two isomers by chromatography were unsuccessful, as reported in the literature for a similar derivative. ${ }^{63}$

HPLC purity was checked with a Dionex C18 analytical column. Using a $\mathrm{CH}_{3} \mathrm{CN}: \mathrm{H}_{2} \mathrm{O}(0.1 \% \mathrm{TFA})$ mixture from $2: 3$ to $1: 0$ in 30 minutes, retention times of the two diastereoisomers of 1 were 14.89 and 15.01 minutes ( $7: 3$ for $\mathrm{CH}_{3} \mathrm{CN}: \mathrm{H}_{2} \mathrm{O}$ ). They were not isolated separately and the integration of both peaks is $>95 \%$ of the whole chromatogram (see Fig. S1†).

We report below ${ }^{1} \mathrm{H}$ and ${ }^{13} \mathrm{C}$ NMR signals for the diastereoisomeric mixture. The integrations for ${ }^{1} \mathrm{H}$ NMR signals are given for the two diastereoisomers. The sign "*” indicates protons with different chemical shifts in the two diastereoisomers and the indices $a$ and $b$ refer to the two diastereoisomers. The major shifts are noticed for ${ }^{1} \mathrm{H}$ present on carbons $5^{\prime \prime}(\mathrm{ca} .8 .6 \mathrm{ppm})$ and $13^{\prime \prime}$ (ca. $7.6 \mathrm{ppm}$ ) from the triazol rings. See the ESI $\dagger$ for the atom numbering.

$1^{1} \mathrm{H} \mathrm{NMR}\left(\mathrm{CDCl}_{3}, 300 \mathrm{MHz}\right) \delta(\mathrm{ppm}): 8.95-8.93\left(2 \mathrm{H}, \mathrm{d}_{\mathrm{a}}(J=4.2\right.$ $\mathrm{Hz})$ and $\mathrm{d}_{\mathrm{b}}(J=4.5 \mathrm{~Hz}), 6^{\prime}-$ pyH $\left.^{*}\right), 8.69$ and $8.64\left(2 \mathrm{H}, \mathrm{s}_{\mathrm{a}}\right.$ and $\mathrm{s}_{\mathrm{b}}$, $5^{\prime \prime}$-triazH*), 7.99-7.92 (4H, m, 4' and $3^{\prime}-$ pyH $\left.^{*}\right), 7.62$ and 7.60 $\left(2 \mathrm{H}, \mathrm{s}_{\mathrm{a}}\right.$ and $\mathrm{s}_{\mathrm{b}}, 13^{\prime \prime}$-triazH*), 7.43-7.39 (2H, m, 5'-pyH $\left.{ }^{*}\right), 7.08$ $(2 \mathrm{H}, \mathrm{d}, 1-\mathrm{ArH}, J=8.6 \mathrm{~Hz}), 6.63(2 \mathrm{H}, \mathrm{dd}, 2-\mathrm{ArH}, J=8.6 \mathrm{~Hz}, J=2.7$ $\mathrm{Hz}), 6.60(2 \mathrm{H}, \mathrm{d}, 4-\mathrm{ArH}, J=2.7 \mathrm{~Hz}), 4.53\left(4 \mathrm{H}, \mathrm{m},-\left(\mathrm{CH}_{2}\right)\right.$-triaz$)$, $4.42\left(4 \mathrm{H}, \mathrm{m},-\left(\mathrm{CH}_{2}\right)\right.$-triaz), $3.75\left(6 \mathrm{H}, \mathrm{s}, 19-\mathrm{CH}_{3}\right), 2.82(4 \mathrm{H}, \mathrm{m}$, 6- $\left.\left(\mathrm{CH}_{2}\right)\right), 2.60\left(4 \mathrm{H}, \mathrm{m}, 7^{\prime \prime}-\left(\mathrm{CH}_{2}\right)\right), 2.35(2 \mathrm{H}, \mathrm{m}), 2.13\left(4 \mathrm{H}, \mathrm{m},-\mathrm{CH}_{2}-\right.$, $-\mathrm{CH}-), 1.94\left(6 \mathrm{H},-\mathrm{CH}_{2^{-}},-\mathrm{CH}-\right), 1.65-1.30\left(12 \mathrm{H}, \mathrm{m},-\mathrm{CH}_{2^{-}},-\mathrm{CH}-\right), 1.03$ $\left(6 \mathrm{H}, \mathrm{s}, 18-\left(\mathrm{CH}_{3}\right)\right), 0.68\left(2 \mathrm{H}, \mathrm{m},-\mathrm{CH}_{2}-\right)$.

$1{ }^{13} \mathrm{C} \mathrm{NMR}\left(\mathrm{CDCl}_{3}, 75 \mathrm{MHz}\right) \delta(\mathrm{ppm}): 197.17$ (C三O), 196.03 $(\mathrm{C} \equiv \mathrm{O}), 188.82$ ( $\mathrm{C} \equiv \mathrm{O}), 157.55$ (3-C), 154.22 (12' $\left.2^{\prime \prime}-\mathrm{C}\right), 153.04$ (6'-pyC), 149.14 (2'-pyC), 148.87 ( $4^{\prime \prime}$-triazC), 139.64 ( $4^{\prime}$-pyC), 137.95 (5-C), 132.58 (10-C), 126.15 (1-C), 125.99 (5'-pyC), 123.84 ( $5^{\prime \prime}$-triazC), 122.60 (13"'-triazC), 122.49 (3'-pyC), 113.91 (4-C), 111.52 (2-C), 82.34 (17-C), 55.21 (19-C), 49.20 (- $\mathrm{CH}_{2}$-triaz), 48.70 (14-C), 47.46 (13-C), 46.60 (- $\mathrm{CH}_{2}$-triaz), 43.43 (9-C), 39.54 (8-C), 38.12 (12-C), 33.14 (16-C), 29.99 (6-C), 29.77 (7"-C), 27.39 (11-C), 26.30 (7-C), 23.46 (15-C), 14.30 (18-C).

HRMS+ (ESI): calcd for $\mathrm{ReC}_{34} \mathrm{H}_{37} \mathrm{O}_{5} \mathrm{~N}_{7} \mathrm{ClNa}\left([\mathrm{M}+\mathrm{Na}]^{+}\right): m / z$ 868.1987. Found: $m / z$ 868.2021.

$\log P_{o / w}$ of 1 was estimated by HPLC chromatography following the recommendations of Minick $^{87}$ and Pomper ${ }^{88}$ using a C-18 silica column (Kromasyl, Interchrom) and uracil as an internal reference. Organic and aqueous phases were used in several proportions $(n=5)$. The organic portion of the mobile phase was composed of methanol containing $0.25 \%(\mathrm{v} / \mathrm{v})$ 1-octanol. The aqueous portion was prepared from octanolsaturated water containing $0.02 \mathrm{M}$ MOPS buffer, and $0.15 \%(\mathrm{v} / \mathrm{v})$ $n$-decylamine, and adjusted to $\mathrm{pH} 7.4$. We found: $\log P_{\mathrm{o} / \mathrm{w}}(\mathbf{1})=$ 5.7 and $\log P_{\mathrm{o} / \mathrm{w}}\left(\mathrm{Re}(\mathrm{CO})_{3}\right.$ Cl-pyta- $\left.\mathrm{C}_{12} \mathrm{~N}_{3}{ }^{12}\right)=7.3$.

\subsection{Biological assays}

MDA-MB-231 and MCF-7 breast cancer cell lines obtained from the Human Tumour Cell Bank were used for the experiments. Cells were maintained in monolayer culture in DMEM with phenol red/Glutamax I, supplemented with $9 \%$ of decomplemented fetal calf serum and $0.9 \%$ kanamycin, at $37{ }^{\circ} \mathrm{C}$ in a $5 \% \mathrm{CO}_{2}$ air humidified incubator. For proliferation assays, cells were seeded in 24-well sterile plates with $1.5 \times 10^{4}$ cells of MDA-MB-231 and $3 \times 10^{4}$ cells of MCF-7 in $1 \mathrm{~mL}$ of DMEM without phenol red, supplemented with $9 \%$ of fetal calf serum desteroided on dextran charcoal, $0.9 \%$ Glutamax I and $0.9 \%$ kanamycin, and grown for $24 \mathrm{~h}$. The following day (D0), $1 \mathrm{~mL}$ of the same medium containing 1 dissolved in DMSO was added to the plates (final volumes of DMSO: $0.1 \% ; 4$ wells for each condition). After three days (D3), the incubation medium was removed and 2 $\mathrm{mL}$ of fresh medium containing 1 was added. At D3, D4, D5 and D6, the protein content of each well was quantified by methylene blue staining as follows. Cell monolayers were fixed and stained for $1 \mathrm{~h}$ in methanol with methylene blue (2 $\mathrm{mg} \mathrm{mL}^{-1}$ ), and then washed thoroughly with water. Two milliliters of $\mathrm{HCl}(0.1 \mathrm{M})$ was then added, and the plate was incubated for $1 \mathrm{~h}$ at $37{ }^{\circ} \mathrm{C}$. Then the absorbance of each well was measured at $655 \mathrm{~nm}$ with a Biorad microplate reader. The results are expressed as the percentage of proteins versus the control. The estrogenic activity (on 
MCF-7) and cytotoxicity ( $\mathrm{IC}_{50}$ on MDA-MB-231) were both determined at D5. Experiments were performed at least in duplicate.

\subsection{Nature of the slides}

Glass slides were used for wide field and confocal fluorescence imaging and Raman microspectroscopy. Calcium fluoride $\left(\mathrm{CaF}_{2}\right)$ slides (purchased from Crystran) were used for synchrotron radiation FTIR (SMIS and IRENI, 1 and $0.2 \mathrm{~mm}$ thick) and UV spectromicroscopies (DISCO, $0.2 \mathrm{~mm}$ thick). These $0.2 \mathrm{~mm}$ thin $\mathrm{CaF}_{2}$ slides are useful windows for multimodal imaging as they are transparent from $190 \mathrm{~nm}$ to $10 \mu \mathrm{m}$; it is then possible to study the same cell by both UV-visible and IR techniques (see Fig. 1, 2 and 6).

\subsection{Cell culture for imaging}

Both control and treated cells were processed in a similar way. They were seeded on slides (deposited in $35 \times 10 \mathrm{~mm}$ Petri dishes) in order to reach confluency after $48 \mathrm{~h}$ of incubation at $37{ }^{\circ} \mathrm{C}$ under an atmosphere of $95 \%$ air $/ 5 \% \mathrm{CO}_{2}$. The nature of the slides for each imaging technique is described in Section 3.3. The medium was removed and fresh growth medium $(2 \mathrm{~mL}$ DMEM without phenol red and supplemented as in Section 3.2) was added to each flask of control cells. In the case of treated cells, $2 \mathrm{~mL}$ of a solution of 1 in fresh growth medium $(25 \mu \mathrm{M}$ prepared from a $5 \times 10^{-3} \mathrm{M}$ stock solution in DMSO) were added. The cells were incubated at $37{ }^{\circ} \mathrm{C}$ under an atmosphere of $95 \%$ air $/ 5 \% \mathrm{CO}_{2}$ for $1 \mathrm{~h}$. The medium was then removed and the cells were washed twice with phosphate buffered saline (D-PBS, $1 \times, 2 \mathrm{~mL}$ ). The cells were fixed with $4 \%$ paraformaldehyde $(1.5 \mathrm{~mL}$ ) for 8 minutes at room temperature and washed once with D-PBS $(1 \times, 2 \mathrm{~mL})$ and once with pure water $(2 \mathrm{~mL})$. Slides were air-dried for IR-imaging and mounted using the Vectashield solution (H-1000, Vector Laboratories) just after the last water washing for luminescence imaging.

\subsection{Fluorescent organelle staining}

For colocalization of the Golgi tracker (BODIPY TR $\mathrm{C}_{5}$-ceramide) and 1, the experiment was performed as follows: growth medium (DMEM without phenol red and supplemented as in Section 3.2) was removed and cells were incubated at $4{ }^{\circ} \mathrm{C}$ with BODIPY TR $\mathrm{C}_{5}$-ceramide complexed to BSA (B-34400, Invitrogen) (2.7 $\mu \mathrm{M}$ in growth medium for 30 minutes). The medium was then removed and the cells were washed twice with cold phosphate buffered saline (D-PBS, $1 \times, 2 \mathrm{~mL}$ ). $2 \mathrm{~mL}$ of a $25 \mu \mathrm{M}$ solution of $\mathbf{1}$ in fresh growth medium (prepared from a $5 \times 10^{-3} \mathrm{M}$ stock solution in DMSO) were then added. The cells were incubated at $37{ }^{\circ} \mathrm{C}$ under an atmosphere of $95 \%$ air/5\% $\mathrm{CO}_{2}$ for a period of $1 \mathrm{~h}$. The medium was then removed and the cells were washed twice with phosphate buffered saline (D-PBS, $1 \times, 2 \mathrm{~mL})$. Cells were fixed with $4 \%$ paraformaldehyde $(1.5 \mathrm{~mL})$ for 8 minutes at room temperature and washed once with D-PBS $(1 \times, 2 \mathrm{~mL})$ and once with pure water $(2 \mathrm{~mL})$. Slides were mounted using the Vectashield solution (H-1000, Vector Laboratories). The nuclei were stained with DAPI (Invitrogen, $15 \mathrm{nM}$ in water) directly on fixed cells, when slides were on the microscope motorized stage.

\subsection{Fluorescence imaging and study of the effect of temperature on cellular uptake}

In-cell fluorescence imaging of 1 was performed using an IX71 (Olympus) microscope equipped with a CCD (Orca-ER, Hamamatsu, Corporation, Sewickley, PA) and X60 (Plan Apo, NA 1.42) objective. 1 was detected using an appropriate filter set (excitation D350/50x; beam splitter 400DCLP; emission HQ560/80m; Chroma Technology) and excited using a $\mathrm{Hg}$ lamp (100 W) attenuated by a neutral density filter (ND-1). The DAPI-stained nucleus was located using a DAPI filter set (excitation D350/50x; beam splitter 400DCLP; emission D460/50m; Chroma Technology) and the BODIPY-stained Golgi using a Texas Red filter set (excitation ET560/40x; beam splitter T585LPXR; emission ET630/ 75m; Chroma Technology). Microscope settings and functions were controlled using Simple PCI software (Hamamatsu). Image analysis was performed using ImageJ Software and Simple PCI software. Colocalization coefficients ${ }^{\mathbf{8 1 , 8 2}}$ were calculated using ImageJ plugin Colocalization Indices. Confocal fluorescence images were taken on a Zeiss LSM 710 confocal microscope using an X63 (NA 1.40) objective and $405 \mathrm{~nm}$ laser excitation. 3D reconstruction of the $z$-stacks was made with ImageJ software.

To study the effect of temperature on the cellular uptake of $\mathbf{1}$, MDA-MB-231 cells were incubated for $1 \mathrm{~h}$ either at $37{ }^{\circ} \mathrm{C}(\mathrm{T} 1)$ or at $4{ }^{\circ} \mathrm{C}(\mathrm{T} 2)$ with a solution of 1 at $25 \mu \mathrm{M}$ (solution previously cooled to $4{ }^{\circ} \mathrm{C}$ for the T2 experiment). The medium was then removed and the cells washed twice with D-PBS $(1 \times, 2 \mathrm{~mL})$. In the case of T2, this step was performed at $4{ }^{\circ} \mathrm{C}$ with cold D-PBS. Cells were then fixed with $4 \%$ paraformaldehyde $(1.5 \mathrm{~mL})$ for 8 minutes at room temperature and washed once with D-PBS $(1 \times$, $2 \mathrm{~mL}$ ) and once with pure water $(2 \mathrm{~mL})$. Slides were mounted using the Vectashield solution (H-1000, Vector Laboratories) just after the last water washing for luminescence imaging. Two independent experiments were performed, each one in duplicate. A series of snapshots using the adequate filter set to monitor 1 (see above) was recorded. For each image, the mean perinuclear luminescence intensity per cell corrected for the background was determined (using ImageJ software). For the three conditions (control/incubation of 1 at $4{ }^{\circ} \mathrm{C} /$ incubation of 1 at $37^{\circ} \mathrm{C}$ ), mean values and error bars were calculated over a large number of cells, respectively 85, 263, 289 (Fig. S3-left $\dagger$ ). For the compound $\mathrm{Re}(\mathrm{CO})_{3}$ Cl-pyta- $\mathrm{C}_{12} \mathrm{~N}_{3}$ that we previously described, ${ }^{12}$ the same protocol was used, using the same filter set as its luminescent properties are identical to 1 . For the three conditions (control/incubation at $4{ }^{\circ} \mathrm{C} /$ incubation at $37{ }^{\circ} \mathrm{C}$ ), mean values and error bars were calculated over a large number of cells, respectively 85, 248, 247 (Fig. S3-right $\dagger$ ).

\subsection{Synchrotron radiation FTIR spectromicroscopy (SR- FTIR-SM)}

Spectra were recorded at the SMIS beamline (Synchrotron SOLEIL, Saint Aubin, France) which exploits the edge and bending radiation of a bending magnet. ${ }^{89}$ Spectra were recorded in transmission mode on a Nicolet Continuum XL microscope 
(Thermo Fisher) equipped with a $50 \times 50 \mu \mathrm{m}^{2}$ liquid nitrogen cooled MCT/A detector, a 32X/NA 0.65 Schwarzschild objective, a Prior XYZ motorised stage, and coupled to a Nicolet 5700 FTIR spectrometer (Thermo Fisher) equipped with a Michelson interferometer and a $\mathrm{KBr}$ beam splitter. The confocal aperture was set at $6 \times 6 \mu \mathrm{m}^{2}$ and the microscope was operated in semiconfocal mode. Spectra were recorded with 200-250 scans at 6 $\mathrm{cm}^{-1}$ resolution in the $1040-3700 \mathrm{~cm}^{-1}$ range. Maps were recorded by raster scanning the cells with steps of $3 \mu \mathrm{m}$ in $X$ and in $Y$ with 180-250 scans at $6 \mathrm{~cm}^{-1}$ resolution in each square. Chemical maps were created with the Omnic software (Thermo Fisher) by measuring and plotting the integral of specific bands (in Fig. 2, the following integration limits were used, E: 1940$1879 \mathrm{~cm}^{-1}$, amide I: $1724-1584 \mathrm{~cm}^{-1}, \mathrm{CH}_{3}$ asym.: 2986-2948 $\mathrm{cm}^{-1}$ and $\mathrm{CH}_{2}$ asym.: $2948-2897 \mathrm{~cm}^{-1}$ for the $\mathrm{CH}_{3} / \mathrm{CH}_{2}$ ratio). Pixels showing more than $80 \%$ of the maximum value for an IR-band are referred to as hot spots and are shown in Fig. 2. The complete mappings with the full range of integration values are presented in Fig. S4.†

\subsection{Synchrotron radiation UV spectromicroscopy (SR-UV-SM)}

Spectra were recorded at the DISCO beamline (Synchrotron SOLEIL, Saint Aubin, France). $\mathrm{CaF}_{2}$ thin slides (see Section 3.3) with fixed cells were deposited onto an inverted glycerin immersion objective (X40 Ultrafluar, CARL ZEISS). Excitation was provided by the fully tuneable excitation from a bending magnet at Synchrotron SOLEIL ${ }^{90}$ (350 $\mathrm{nm}$ excitation with a $0.2 \mathrm{~nm}$ bandpass). Rastering of the sample allows us to record $(x, y, \lambda, I)$ maps with $3 \times 3 \mu \mathrm{m}^{2}$ pixel size, with $100-120 \mathrm{~s}$ acquisition time per spectrum. The fluorescence emission spectrum of the selected pixels was recorded by a spectrograph. ${ }^{\mathbf{9 1}}$

\subsection{AFMIR}

AFMIR is an emerging and cutting-edge near-field technique ${ }^{92}$ using an AFM (Atomic Force Microscope) and a tuneable infrared pulsed laser to record spatially resolved absorption measurements. ${ }^{93-95}$ The AFM tip is in contact with the sample that is illuminated by a pulsed laser beam through a ZnSe prism. The laser wavelength is tuned to an IR-absorption band of the molecule of interest and when the laser pulse occurs, the temperature increases with local temporary deformations. The AFM-tip detects these local deformations and starts to oscillate. The maximal amplitude of this oscillation, which corresponds to the AFMIR signal, is proportional to the local absorbance. ${ }^{96}$ This technique has a resolution from $100 \mathrm{~nm}$ to $20 \mathrm{~nm}$ (ref. 97) thus allowing sub-cellular IR-mapping of biological samples. ${ }^{98}$ Here we used thin $\mathrm{CaF}_{2}$ slides (see Section 3.3) laid on the upper surface of the ZnSe prism with paraffin oil in between to make a good optical contact and avoid evanescent waves in the air gap. The AFM was a FlexAFM from the Nanosurf company, and the tuneable laser source was the free electron laser CLIO (French Free Electron Laser facility based in the Laboratoire de Chimie Physique at the Universite Paris-Sud at Orsay).

\subsection{Confocal Raman microspectroscopy and imaging}

Raman spectra were recorded using a WITec (Ulm, Germany) Alpha300RS confocal Raman microscope. The excitation wavelength of $532 \mathrm{~nm}$ was provided by a frequency-doubled Nd:YAG laser. The beam was focused on the sample using an Olympus $(100 \times / 0.95 \mathrm{NA})$ objective, and the power at the sample was close to $1 \mathrm{~mW}$. The sample was located on a piezoelectrically driven microscope scanning stage, with a $x, y$ resolution of $5 \mathrm{~nm}$, and a $z$-resolution of $2 \mathrm{~nm}$. The integration time for each spectrum was $2 \mathrm{~s}$. A spectrum was recorded every $1 \mu \mathrm{m}$ along the $x$ and $y$ directions. The image resulted in about $625(25 \times 25)$ spectra and $1250 \mathrm{~s}$ total acquisition time.

\subsection{Synchrotron-based multiple beam FTIR imaging}

The synchrotron-based multiple beam FTIR imaging instrument called IRENI, as recently implemented at the Synchrotron Radiation Center (Stoughton, Wisconsin, USA), couples a synchrotron source extracting an entire bending magnet of radiation to a FTIR microscope (Bruker Hyperion 3000) equipped with a FPA detector $(128 \times 128$ pixels $) .{ }^{99,100}$ The imaging system extracts 12 beams from a bending magnet. A set of mirrors creates a bundle of a $3 \times 4$ beam matrix that is able to illuminate $96 \times 96$ pixels of a FPA detector, where each pixel corresponds to $0.54 \times 0.54 \mu^{2}$ area of the sample. Thus, several thousands of individual FTIR spectra are collected concurrently for a $52 \times 52 \mu^{2}$ sample area within a few minutes allowing rapid, high spatially and spectrally resolved chemical imaging and thereby providing chemical images of the investigated sample area. The lateral spatial resolution achievable with this widefield imaging approach is equivalent to or is better than the confocal geometry employed at traditional synchrotron beamlines when the effective sample area evaluated with defining apertures is larger than $1 \mu \mathrm{m}^{2} .{ }^{101}$ For the present investigations, FTIR data were collected in transmission mode as hyperspectral cubes $(x, y, \operatorname{Abs}(n))$ using a $74 \times$ objective $(\mathrm{NA}=0.65)$ and a $15 \times$ condenser $(\mathrm{NA}=0.65)$. The size of the FPA detector was $64 \times 64$ pixels and simultaneously 4096 single FTIR spectra were recorded corresponding to $34 \times 34 \mu^{2}$ area with a pixel resolution of $0.54 \mu \mathrm{m}$. The FTIR data were obtained over the range of $3800-1000 \mathrm{~cm}^{-1}$ and were generated from co-adding 128 scans at $4 \mathrm{~cm}^{-1}$ spectral resolution. The following integration parameters were used in Fig. 5 and $\mathrm{S} 7 \dagger$ (with straight baselines from the integration endpoints): amide I: $1680-1612 \mathrm{~cm}^{-1}$, E: $1932-1890 \mathrm{~cm}^{-1}$ and $\mathrm{A}_{1}$ : 2033$2013 \mathrm{~cm}^{-1}$. The resulting spectra and FTIR imaging data were evaluated by using homemade software IRidys (https:// www.IRidys.com, accessed December 2012 4th) running under IGOR Pro 6.22.

\subsection{FTIR spectra acquisition}

Spectra were recorded on a Perkin Elmer Spectrum 100 equipped with an ATR sampling accessory and analysed using Perkin Elmer Spectrum software. The FTIR spectra of a thin film of 1 obtained after evaporation of a solution of 1 in methanol and of mestranol as a solid are shown in Fig. S2. $\dagger$ 
3.13 UV-visible absorption and luminescence emission in vitro

Solutions of 1 in different organic solvents were studied in quartz cuvettes with a Varian Cary 300 Bio UV-Visible Spectrophotometer. Spectral analysis was performed using Cary Win UV software. A Jasco FP-8300 Spectrofluorimeter (with Spectra Manager software) was used to monitor emission properties of 1 .

\section{Conclusion}

In the intricate context of the estrogen receptor location, we report here the successful multimodal imaging of mestranol coupled with a single rhenium-pyta carbonyl bimodal core using a large set of spectroscopic techniques. Luminescent and vibrational properties of the SCoMPI enabled the detection of 1 inside fixed MCF-7 and MDA-MB-231 breast cancer cells. 1 displays estrogenic activity, suggesting the targeting of nuclear estrogen receptors. At that point, the presence of $\mathbf{1}$ at low concentrations in the nucleus cannot be excluded, but there is a clear accumulation in a perinuclear location evidenced by several independent imaging techniques. Further colocalization studies using a fluorescent Golgi tracker clearly showed colocalization of $\mathbf{1}$ with the Golgi apparatus in both cell lines. However non-specific accumulation in the Golgi that could play the role of a reservoir cannot be excluded, especially when the nuclear estrogen receptors are found to be in low concentrations. What is significant is that the images obtained from these independent techniques consistently depict accumulation inside the Golgi apparatus.

These results clearly demonstrate that SCoMPIs are relevant low-molecular weight and easy-to-conjugate probes, enabling the gathering of reliable information from independent imaging techniques. By exploiting the different capabilities of the various techniques i.e. high lateral resolution in fluorescence or micro-Raman imaging, photo-bleaching-free synchrotron-based micro-FTIR using raster scanning or focal plane array detection, and high resolution in AFMIR, this $\mathrm{LRe}(\mathrm{CO})_{3}$ probe is a valuable tool for answering biology-related questions concerning locations with versatile constraints.

This multiple capability of a single probe is an asset as several questions can be addressed by its unique conjugation with a biomolecule.

\section{Abbreviations}

$\begin{array}{ll}\text { AFMIR } & \text { Atomic Force Microscope-InfraRed } \\ \text { BSA } & \text { Bovine Serum Albumin } \\ \text { BODIPY } & \text { boron-dipyrromethene (dye) } \\ \text { CLIO } & \text { Centre Laser Infra-Rouge d'Orsay } \\ \text { DAPI } & \begin{array}{l}\text { ',6-diamidino-2-phenylindole (nucleus } \\ \text { tracker) }\end{array} \\ \text { DISCO } & \text { Dichroism, Imaging and mass Spectrometry } \\ & \text { for Chemical and biOlogical systems } \\ \text { DMEM } & \text { Dulbecco Modified Eagle Medium } \\ \text { DMSO } & \text { DiMethylSulfOxide } \\ \text { DPBS } & \text { Dulbecco's Phosphate Buffer Saline }\end{array}$

$\begin{array}{ll}\text { ER } & \text { Nuclear Estrogen Receptor } \\ \text { GPR30 } & \text { G-protein coupled estrogen receptor } \\ \text { HCA } & \text { Hierarchical Cluster Analysis } \\ \text { HPLC } & \text { High Performance Liquid Chromatography } \\ \text { HRMS+ (ESI) } & \begin{array}{l}\text { High Resolution Mass Spectrometry, positive } \\ \text { mode, ElectroSpray Ionisation }\end{array} \\ \text { IRENI } & \text { InfraRed ENvironmental Imaging } \\ \text { MCF-7 and MDA- } & \text { Breast cancer cell lines } \\ \text { MB-231 } & \\ \text { MLCT } & \text { Metal-to-Ligand Charge Transfer } \\ \text { MOPS } & \text { 3-(N-morpholino)propanesulfonic acid } \\ \text { MW } & \text { Molecular Weight } \\ \text { Pyta } & \text { 4-(2-pyridyl)-1,2,3-triazole } \\ \text { SCoMPI } & \text { Single Core Multimodal Probe for Imaging } \\ \text { SMIS } & \text { Spectroscopy and Microscopy in the Infrared } \\ & \text { using Synchrotron } \\ \text { SR-FTIR-SM } & \text { Synchrotron Radiation Fourier Transform } \\ \text { SR-UV-SM } & \text { InfraRed SpectroMicroscopy } \\ & \text { Synchrotron Radiation UV } \\ & \text { SpectroMicroscopy; synchrotron beamlines }\end{array}$

\section{Acknowledgements}

This work is based on research conducted at the Ecole Normale Supérieure (ENS), CNRS (UMR7203, 8640, 8000, 7223 and 5248), Université Pierre et Marie Curie Paris 6, Université Paris-Sud and Université de Bordeaux. These institutions are gratefully acknowledged for their financial support. In addition, ENS is acknowledged for SC's PhD fellowship, the Groupe Français de Chimie Bio-inorganique is acknowledged for SC's international fellowship for experiments at SRC, and CNRS is acknowledged for financial support in the context of programme PCV prise de risque. We thank the SOLEIL committee for beamtime and financial support in the conduct of experiments at SOLEIL (project 20111026) and the CLIO committee for beamtime for AFMIR experiments. This work is based on research conducted at the IRENI beamline the construction and development of which was supported by the U.S. National Science Foundation under award MRI-0619759. This work was supported by the U.S. National Science Foundation under grant CHE-1112433. The Synchrotron Radiation Center is primarily funded by the University of Wisconsin-Madison with supplemental support from facility Users and the University of Wisconsin-Milwaukee.

\section{Notes and references}

1 S. G. Kazarian and K. L. A. Chan, Analyst, 2013, 138, 1940 1951.

2 L. M. Miller and P. Dumas, Biochim. Biophys. Acta, Biomembr., 2006, 1758, 846-857.

3 H. Amrania, A. P. McCrow, M. R. Matthews, S. G. Kazarian, M. K. Kuimova and C. C. Phillips, Chem. Sci., 2011, 2, 107111.

4 M. K. Kuimova, K. L. A. Chan and S. G. Kazarian, Appl. Spectrosc., 2009, 63, 164-171.

5 C. Policar, J. B. Waern, M. A. Plamont, S. Clède, C. Mayet, R. Prazeres, J.-M. Ortega, A. Vessières and A. Dazzi, Angew. Chem., Int. Ed., 2011, 50, 860-864. 
6 A. Vessières, S. Top, A. A. Ismail, I. S. Butler, M. Louer and G. Jaouen, Biochemistry, 1988, 27, 6659-6665.

7 G. R. Stephenson, in Bioorganometallics: Biomolecules, Labeling, Medicine, ed. G. Jaouen, Wiley-VCH, Weinheim, 2006, pp. 215-262.

8 M. Salmain, A. Vessières, A. Varenne, P. Brossier and G. Jaouen, J. Organomet. Chem., 1999, 589, 92-97.

9 A. Marcelli, A. Cricenti, W. M. Kwiatek and C. Petibois, Biotechnol. Adv., 2012, 30, 1390-1404.

10 K. V. Kong, W. Chew, L. H. K. Lim, W. Y. Fan and W. K. Leong, Bioconjugate Chem., 2007, 18, 13701374.

11 S. Clède, F. Lambert, C. Sandt, Z. Gueroui, N. Delsuc, P. Dumas, A. Vessières and C. Policar, Biotechnol. Adv., 2013, 31, 393-395.

12 S. Clède, F. Lambert, C. Sandt, Z. Gueroui, M. Refregiers, M.-A. Plamont, P. Dumas, A. Vessieres and C. Policar, Chem. Commun., 2012, 48, 7729-7731.

13 I. S. Butler, R. P. Kengne-Momo, G. Jaouen, C. Policar and A. Vessieres, Appl. Spectrosc. Rev., 2012, 47, 531-549.

14 K. Meister, J. Niesel, U. Schatzschneider, N. Metzler-Nolte, D. A. Schmidt and M. Havenith, Angew. Chem., Int. Ed., 2010, 49, 3310-3312.

15 P. Hildebrandt, Angew. Chem., Int. Ed., 2010, 49, 4540-4541. 16 M. Patra and G. Gasser, ChemBioChem, 2012, 13, 12321252.

17 M. Wrighton and D. L. Morse, J. Am. Chem. Soc., 1974, 96, 998-1003.

18 L. Sacksteder, A. P. Zipp, E. A. Brown, J. Streich, J. N. Demas and B. A. DeGraff, Inorg. Chem., 1990, 29, 4335-4340.

19 M. Bartholoma, J. Valliant, K. P. Maresca, J. Babich and J. Zubieta, Chem. Commun., 2009, 493-512.

20 F. L. Thorp-Greenwood, R. G. Balasingham and M. P. Coogan, J. Organomet. Chem., 2012, 714, 12-21.

21 R. G. Balasingham, M. P. Coogan and F. L. ThorpGreenwood, Dalton Trans., 2011, 40, 11663-11674.

22 V. Fernandez-Moreira, F. L. Thorp-Greenwood and M. P. Coogan, Chem. Commun., 2010, 46, 186-202.

23 K. K.-W. Lo, A. W.-T. Choi and W. H.-T. Law, Dalton Trans., 2012, 41, 6021-6047.

24 K. K.-W. Lo, K. Y. Zhang and S. P.-Y. Li, Eur. J. Inorg. Chem., 2011, 2011, 3551-3568.

25 K. K.-W. Lo, M.-W. Louie and K. Y. Zhang, Coord. Chem. Rev., 2010, 254, 2603-2622.

26 E. Baggaley, J. A. Weinstein and J. A. G. Williams, Coord. Chem. Rev., 2012, 256, 1762-1785.

27 E. V. Jensen and E. R. DeSombre, Science, 1973, 182, 126134.

28 G. G. J. M. Kuiper, E. Enmark, M. Pelto-Huikko, S. Nilsson and J.-A. Gustafsson, Proc. Natl. Acad. Sci. U. S. A., 1996, 93, 5925-5930.

29 C. Carmeci, D. A. Thompson, H. Z. Ring, U. Francke and R. J. Weigel, Genomics, 1997, 45, 607-617.

30 G. Notas, M. Kampa, V. Pelekanou and E. Castanas, Steroids, 2012, 77, 943-950.

31 S. Niro, E. Pereira, M.-A. Pelissier, R. Morfin and O. Hennebert, Steroids, 2012, 77, 542-551.
32 E. J. Filardo, J. A. Quinn, A. R. Frackelton, Jr and K. I. Bland, Mol. Endocrinol., 2002, 16, 70-84.

33 S. Dong, S. Terasaka and R. Kiyama, Environ. Pollut., 2011, 159, 212-218.

34 S. P. Fraser, I. Ozerlat-Gunduz, R. Onkal, J. K. J. Diss, D. S. Latchman and M. B. A. Djamgoz, J. Cell. Physiol., 2010, 224, 527-539.

35 C. M. Revankar, D. F. Cimino, L. A. Sklar, J. B. Arterburn and E. R. Prossnitz, Science, 2005, 307, 1625-1630.

36 M. Maggiolini and D. Picard, J. Endocrinol., 2010, 204, 105114.

37 E. R. Prossnitz, J. B. Arterburn and L. A. Sklar, Mol. Cell. Endocrinol., 2007, 265-266, 138-142.

38 K. Matsuda, H. Sakamoto, H. Mori, K. Hosokawa, A. Kawamura, M. Itose, M. Nishi, E. R. Prossnitz and M. Kawata, Neurosci. Lett., 2008, 441, 94-99.

39 H. Sakamoto, K.-i. Matsuda, K. Hosokawa, M. Nishi, J. F. Morris, E. R. Prossnitz and M. Kawata, Endocrinology, 2007, 148, 5842-5850.

40 M. Reisgys, F. Wust, R. Alberto, R. Schibli, P. A. Schubiger, H.-J. Pietzsch, H. Spies and B. Johannsen, Bioorg. Med. Chem. Lett., 1997, 7, 2243-2246.

41 R. J. Miksicek, K. E. Carlson, K.-J. Hwang and J. A. Katzenellenbogen, Mol. Endocrinol., 1995, 9, 592-604.

42 H. F. VanBrocklin, K. E. Carlson, J. A. Katzenellenbogen and M. J. Welch, J. Med. Chem., 1993, 36, 1619-1629.

43 J. Shani, A. Gazit, T. Livshitz and S. Biran, J. Med. Chem., 1985, 28, 1504-1511.

44 F. Benard, N. Ahmed, J.-M. Beauregard, J. Rousseau, A. Aliaga, C. Dubuc, E. Croteau and J. E. Lier, Eur. J. Nucl. Med. Mol. Imaging, 2008, 35, 1473-1479.

45 L. G. Luyt, H. M. Bigott, M. J. Welch and J. A. Katzenellenbogen, Bioorg. Med. Chem., 2003, 11, 4977-4989.

46 H. M. Bigott, E. Parent, L. G. Luyt, J. A. Katzenellenbogen and M. J. Welch, Bioconjugate Chem., 2005, 16, 255264.

47 H. Enginar, P. Unak, F. Y. Lambrecht, F. Z. Biber Muftuler and E. I. Medine, In Vivo, 2008, 22, 93-100.

48 P. M. Martin, H. P. Magdelenat, B. Benyahia, O. Rigaud and J. A. Katzenellenbogen, Cancer Res., 1983, 43, 4956-4965.

49 M. Okamoto, S. Kobayashi, H. Ikeuchi, S. Yamada, K. Yamanouchi, K. Nagasawa, S. Maekawa, T. Kato and I. Shimizu, Steroids, 2012, 77, 845-849.

50 I. Jose, K. D. Deodhar, U. B. Desai and S. Bhattacharjee, J. Fluoresc., 2011, 21, 1171-1177.

51 B. Fisher, N. Gunduz, S. Zheng and E. A. Saffer, Cancer Res., 1982, 42, 540-549.

52 E. L. Rickert, S. Oriana, C. Hartman-Frey, X. Long, T. T. Webb, K. P. Nephew and R. V. Weatherman, Bioconjugate Chem., 2010, 21, 903-910.

53 K. K.-W. Lo, K. H.-K. Tsang, K.-S. Sze, C.-K. Chung, T. K.-M. Lee, K. Y. Zhang, W.-K. Hui, C.-K. Li, J. S.-Y. Lau, D. C.-M. Ng and N. Zhu, Coord. Chem. Rev., 2007, 251, 2292-2310.

54 K. K.-W. Lo, T. K.-M. Lee, J. S.-Y. Lau, W.-L. Poon and S.-H. Cheng, Inorg. Chem., 2008, 47, 200-208. 
55 K. K.-W. Lo, K. H.-K. Tsang and N. Zhu, Organometallics, 2006, 25, 3220-3227.

56 R. Masyuko, E. J. Lanni, J. V. Sweedler and P. W. Bohn, Analyst, 2013, 138, 1924-1939.

57 T. A. Ternes, H. Andersen, D. Gilberg and M. Bonerz, Anal. Chem., 2002, 74, 3498-3504.

58 A. Nelson, Int. J. Women's Health, 2010, 2, 99-106.

59 A. Vessieres, S. Top, C. Vaillant, D. Osella, J. Mornon and G. Jaouen, Angew. Chem., Int. Ed. Engl., 1992, 104, 790-792.

60 J. B. Arterburn, C. Corona, K. V. Rao, K. E. Carlson and J. A. Katzenellenbogen, J. Org. Chem., 2003, 68, 7063-7070.

61 V. Novakova, P. Zimcik, M. Miletin, K. Kopecky and J. Ivincova, Tetrahedron Lett., 2010, 51, 1016-1018.

62 N. V. Sokolova and V. G. Nenajdenko, Chem. Heterocycl. Compd., 2012, 48, 903-906.

63 C. B. Anderson, A. B. S. Elliott, C. J. McAdam, K. C. Gordon and J. D. Crowley, Organometallics, 2013, 32, 788-797.

64 F. Wust, M. B. Skaddan, P. Leibnitz, H. Spies, J. A. Katzenellenbogen and B. Johannsen, Bioorg. Med. Chem., 1999, 7, 1827-1835.

65 C. Ramesh, B. J. Bryant, T. Nayak, C. M. Revankar, T. Anderson, K. E. Carlson, J. A. Katzenellenbogen, L. A. Sklar, J. P. Norenberg, E. R. Prossnitz and J. B. Arterburn, J. Am. Chem. Soc., 2006, 128, 14476-14477.

66 T. W. Spradau and J. A. Katzenellenbogen, Bioorg. Med. Chem. Lett., 1998, 8, 3235-3240.

67 K.-L. Dao, R. R. Sawant, J. A. Hendricks, V. Ronga, V. P. Torchilin and R. N. Hanson, Bioconjugate Chem., 2012, 23, 785-795.

68 M. Salmain, A. Vessières, G. Jaouen and I. S. Butler, Anal. Chem., 1991, 63, 2323-2329.

69 T. Y. Kim, A. B. S. Elliott, K. J. Shaffer, C. J. McAdam, K. C. Gordon and J. D. Crowley, Polyhedron, 2013, 52, 1391-1398.

70 A. Boulay, A. Seridi, C. Zedde, S. Ladeira, C. Picard, L. Maron and E. Benoist, Eur. J. Inorg. Chem., 2010, 50585062.

71 M. Obata, A. Kitamura, A. Mori, C. Kameyama, J. A. Czaplewska, R. Tanaka, I. Kinoshita, T. Kusumoto, H. Hashimoto, M. Harada, Y. Mikata, T. Funabiki and S. Yano, Dalton Trans., 2008, 3292-3300.

72 R. Burai, C. Ramesh, T. K. Nayak, M. K. Dennis, B. K. Bryant, E. R. Prossnitz and J. B. Arterburn, PLoS One, 2012, 7, e46861.

73 E. A. Hillard, A. Vessieres, S. Top, P. Pigeon, K. Kowalski, M. Huche and G. Jaouen, J. Organomet. Chem., 2007, 692, 1315-1326.

74 D.-H. Han, H. Tachibana and K. Yamada, In Vitro Cell. Dev. Biol.: Anim., 2001, 37, 275-282.

75 A. Gupta, D. Mandal, Y. Ahmadibeni, K. Parang and G. Bothun, Eur. Biophys. J., 2011, 40, 727-736.

76 D. Colin, A. Lancon, D. Delmas, G. Lizard, J. Abrossinow, E. Kahn, B. Jannin and N. Latruffe, Biochimie, 2008, 90, 1674-1684.

77 M. D. Bartholoma, A. R. Vortherms, S. Hillier, J. Joyal, J. Babich, R. P. Doyle and J. Zubieta, Dalton Trans., 2011, 40, 6216-6225.
78 C. Sandt, J. Frederick and P. Dumas, J. Biophotonics, 2013, 6, 60-72.

79 T. Dieing, O. Hollricher and J. Toporski, Confocal Raman Spectroscopy, Springer, 2010.

80 E. Gazi, J. Dwyer, N. P. Lockyer, J. Miyan, P. Gardner, C. Hart, M. Brown and N. W. Clarke, Biopolymers, 2005, 77, 18-30.

81 V. Zinchuk and O. Grossenbacher-Zinchuk, Curr. Protoc. Cell Biol., 2011, ch. 4, Unit4 19.

82 Q. Li, A. Lau, T. J. Morris, L. Guo, C. B. Fordyce and E. F. Stanley, J. Neurosci., 2004, 24, 4070-4081.

83 J. M. Hall, J. F. Couse and K. S. Korach, J. Biol. Chem., 2001, 276, 36869-36872.

84 K. P. Yang and N. A. Samaan, Cancer Res., 1983, 43, 3534-3538. 85 C. M. Revankar, H. D. Mitchell, A. S. Field, R. Burai, C. Corona, C. Ramesh, L. A. Sklar, J. B. Arterburn and E. R. Prossnitz, ACS Chem. Biol., 2007, 2, 536-544.

86 C. Otto, B. Rohde-Schulz, G. Schwarz, I. Fuchs, M. Klewer, D. Brittain, G. Langer, B. Bader, K. Prelle, R. Nubbemeyer and K.-H. Fritzemeier, Endocrinology, 2008, 149, 4846-4856.

87 D. J. Minick, J. H. Frenz, M. A. Patrick and D. A. Brent, J. Med. Chem., 1988, 31, 1923-1933.

88 M. G. Pomper, H. VanBrocklin, A. M. Thieme, R. D. Thomas, D. O. Kiesewetter, K. E. Carlson, C. J. Mathias, M. J. Welch and J. A. Katzenellenbogen, J. Med. Chem., 1990, 33, 3143-3155.

89 P. Dumas, F. Polack, B. Lagarde, O. Chubar, J. L. Giorgetta and S. Lefrancois, Infrared Phys. Technol., 2006, 49, 152-160.

90 A. Giuliani, F. Jamme, V. Rouam, F. Wien, J.-L. Giorgetta, B. Lagarde, O. Chubar, S. Bac, I. Yao, S. Rey, C. Herbeaux, J.-L. Marlats, D. Zerbib, F. Polack and M. Refregiers, J. Synchrotron Radiat., 2009, 16, 835-841.

91 F. Jamme, S. Villette, A. Giuliani, V. Rouam, F. Wien, B. Lagarde and M. Refregiers, Microsc. Microanal., 2010, 16, 507-514.

92 A. Dazzi, M. Reading, P. Rui and K. Kjoller, Patent WO/ 2008/143817, 2008.

93 A. Dazzi, R. Prazeres, F. Glotin and J.-M. Ortega, Infrared Phys. Technol., 2006, 49, 113-121.

94 A. Dazzi, R. Prazeres, F. Glotin and J.-M. Ortega, Ultramicroscopy, 2007, 107, 1194-1200.

95 A. Dazzi, R. Prazeres, F. Glotin, J.-M. Ortega, M. Al-Sawaftah and M. de Frutos, Ultramicroscopy, 2008, 108, 635-641.

96 A. Dazzi, F. Glotin and R. Carminati, J. Appl. Phys., 2010, 107, 124519.

97 C. Mayet, A. Deniset, R. Prazeres, J.-M. Ortega and A. Dazzi, Biotechnol. Adv., 2013, 31, 369-374.

98 A. Dazzi and C. Policar, in Biointerface Characterization by Advanced IR Spectroscopy, ed. C.-M. Pradier and Y. Chabal, Elsevier, 2011, pp. 245-278.

99 C. J. Hirschmugl and K. M. Gough, Appl. Spectrosc., 2012, 66, 475-491.

100 M. J. Nasse, M. J. Walsh, E. C. Mattson, R. Reininger, A. Kajdacsy-Balla, V. Macias, R. Bhargava and C. J. Hirschmugl, Nat. Methods, 2011, 8, 413-416.

101 E. C. Mattson, M. Unger, B. Manandhar, Z. Alavi and C. J. Hirschmugl, J. Phys.: Conf. Ser., 2013, 425, 142001. 